\title{
The Causality between Gross Fixed Capital Formation, Trade Deficit, Exchange Rate, and the Economic Growth of Pakistan
}

\author{
SALMA ZAHIR \\ Lecturer, Department of Economics Women's University Swabi. \\ Email: salmazahir56@yahoo.com \\ Dr. KAUSER HAYAT \\ Assistant Professor, Department Center for Management \& Commerce, \\ University of Swat Shangla Campus. \\ Email: kausar.hayat87@yahoo.com
}

\begin{abstract}
AFTAB HAIDER
Assistant Professor, Department of Business Studies Bahria University Islamabad.

Email: aftabhaider@bahria.edu.pk
\end{abstract}

\begin{abstract}
The research paper studies the causal link between gross domestic product, gross fixed-capital formations, exchange rate, and trade deficits in Pakistan from 1986 to 2013 with time serial data. ADF and Phillip Perron tests are recycled for stationary and at the first difference, each variable is unified. According to the Johansen Co-integration test, the presence of longer-term Co-integration among variables is displayed, and the Error Correction model expresses that $49.27 \%$ of short-term uncertainty is adjusted in long-term equilibrium. Moreover, the Granger causality test presented causality among the variables. While the conclusion showed that such variables have unidirectional causation.
\end{abstract}

Keywords: Trade Deficit, Exchange Rate, Gross Fixed Capital Formation, Gross Domestic Product, ADF, Phillip Perron, Johansen Co-integration, Error Correction model, \& Granger Causality test.

\section{Introduction}

\section{Economic Growth}

Economically speaking, "economic growth" essentially requires the progression share of production, i.e. the growth of productivity and amenities at "a complete level of employment," which has traditionally led to the upsurge and growth in accumulative demand. In general, most economists used GDP growth rates to measure it.

Henderson and Poole (1991) argued that economic growth over a certain time was the expansion of outputs, as well as additional measures of substantial growth. The growth of productive measurement requires promoting in natural and human reserves. The progress and prosperity of the economy can thus be accomplished by growing production factors like labor, land, raw material, capital, and technology. For a certain period, economic growth is a rise in real per capita income. A developed country creates more production for a long period. As a result, economic development shifts towards expansion as a nation raise its productivity, which further increases its output. 
Economic growth is linked to the economic principle that determines the level of the economy in the long phase of the boom. As a consequence, national income accounting aggregates, such as GNP or GDP, with relevant industry indicators and advanced processes for the generation of an organic compound, steel, and other industrial commodities are generally calculated by an annual improvement in the percentage of the growth rate of the economy.

\section{Gross Fixed Capital Formation}

Capital formation refers to "capital stock," one of the core components of the ability of the economy to generate profits is the capital stock. The production of capital development may increase income, exports, and decreasing imports in LDC, s. If boosted income is correctly and fairly spread among citizens, it will lead to stimulating economic well-being and job opportunities and will further assist to reduce poverty and high foreign earnings.

Gross fixed capital formation measures the quantity of current investment and savings income to increase inflow income and output. Accumulation of capital is equivalent to the enlarging of a country's tangible equity by investing money in both economic and social infrastructures.

\section{Trade Deficit}

The review explored the relationship between economic growth and the trade deficit in Pakistan. The trade deficit shows that imports are growing relative to exports of the economy. Generally, some analysts have a dissimilar view of trade deficits. Some analysts claim that capital inflows are a positive indicator of economic growth, such as a rise in gross domestic product and job prospects, although others suggest that they are detrimental to the economy. However, some analysts conclude that incoming capital is a positive indication of economic development and is closely linked to each other. Capital inflows are the strongest sources of economic development for a trade deficit, and this situation, therefore, tends to stimulate funding and thus improve the supply of merchandise and amenities.

Trade is a tool for Pakistan's economic growth. Economic development and poverty reduction are also hidden within the sense of trade liberalization. Trade is used as a medium for economic growth and is responsible for the allocation of capital in the economy. Trade liberalization is enlarging the efficiency of financial development. In worse developed economies, the production rate is higher than that of imports as they release basic products.

\section{Exchange Rate}

The exchange rate is well-illustrated as the foreign currency rate of the domestic country. Exchange rates are related to binary variables such as domestic and foreign currency and can be estimated either directly or indirectly.

In this time of globalization, the exchange rate is a critical factor. Every country needs to trade globally at low currency rates, making its exports cheaper and more costly to import. Currency appreciation has a stronger effect on the overseas market. The exchange rate has also lead to a larger change in foreign direct investment. In the case of foreign investment, a certain amount of risk and volatility may have arisen due to the exchange rate. Thus the exchange rate has the most important characteristics for determining the effect of the exchange rate on Pakistan's economic development. The exchange rate has also brought about a greater change in direct foreign investment. In the case of foreign investment also a certain amount of risk and uncertainty might have grown due to the exchange rate. Thus the exchange rate has the most significant characteristics to evaluate the shock of the exchange rate on Pakistan's growth rate. 
The researcher found that the exchange rate provides help for entering the price system of one country with other countries in the world market, as well as to bring about a shift in the export and import rate and also in the balance of payments situation of the country.

The current research consisted of the following chapters; Chapter One consists of the basic details of the variables used. Chapter Two is about reviewing previous works. Chapter Three covers research methods, data sources, and analytical techniques. Chapter Four provides a comprehensive analysis of the results and various statistical tools of E-VIEW version 9. Chapter five delivers conclusion, \& recommendation.

\section{Statement of the Study}

According to current literature, numerous works on capital formation and economic growth, especially in Nigeria and other countries, has been conducted and many researchers have used multiple models to analyze the influence and association between such variables and to conclude various outcomes. Several scholars have also focused on the effects of the trade deficit and the exchange rate on economic growth. According to the recent study, there is no specific research evaluating the interaction between the exchange rate, trade deficit, gross fixed capital investment, and economic growth in Pakistan. Recent research has sought to measure and evaluate the impact, interaction \& causality between these factors and economic growth to address the existing void to some level.

\section{Objectives of the Study}

1. To estimate the short and long-term correlation between Pakistan's economic growth, exchange rate, trade deficit, and gross fixed capital formation.

2. To examine the causal trend in Pakistan's economic growth, trade deficit, exchange rate, and gross fixed capital formation.

\section{Research Questions}

1. Is there any connection between Pakistan's economic growth, trade deficit, exchange rate, and gross fixed capital formation?

2. Is there any direction of causality between Pakistan's economic growth, trade deficit, exchange rate, and gross fixed capital formation?

\section{Significance of the Study}

The current study provides a deeper understanding and conception of selected variables affecting Pakistan's economic growth and also recognizes at what point Pakistan's growth rate is not going well. The current study, therefore, used various econometric techniques to identify the connection and causality amongst trade deficit, exchange rate, gross fixed capital formation, and economic growth of Pakistan under all favorable and unfavorable circumstances.

\section{Literature Review}

Adhikary, K-B. (2011), with time-series data from 1986 to 2008 addressed the relationship between capital development, trade openness, foreign direct investment, and economic growth in Bangladesh. At first differences, the ADF and PP stationary tests were considered stationary. The outcomes revealed a robust, long period of steady correlation between GDP \& the explanatory variables as well as clarified the unidirectional causation. 
Ahmed, et.al (2013), used data from the time series to research the relationship between Pakistan's economic growth and trade deficit from 1971 to 2007. Within the ADF and PP test, all variables were stationary. The co-integration test in Johansen presented that FDI has substantial optimistic results, whereas the trade deficit has adverse yet insignificant links to economic growth. The ECM results exhibited the entire variables related to GDP were robust and statistically substantial.

Ahmed, et.al (2014), with time-series data from 2007 to 2013, calculated the exchange rate impact on Pakistan's balance of payments. The ARDL showed that the effect of the EXRT lag on BOP has been significant and positive. While the granger causality test indicated unidirectional causality between BOP and EXRT.

Ainabor, et.al (2014), used data from 1960-2010 with time series to observe the interconnection between economic growth and capital accumulation in Nigeria. To verify important links between Nigeria's growth rate and capital formation, the Harrods - Domer model was applied. The study was taken a unit root test for stationary while the Johansson Co-integration test related to a short and long relationship and the ECM was calculated for speed of adjustment change. The Harrods-Domer model demonstrated a positive interconnection between the increasing rate of national income and capital accumulation and saving ratio.

Bakare, S.A. (2011), clarified the relationship between Nigeria's accumulation of capital and economic growth from 1979 to 2009 with annual data. To discover the connection between capital formation and economic growth, the Harrods - Domer model was chosen. The conclusion showed stationary and cointegration, as well as an essential association between economic growth and gross fixed capital formation in Nigeria. In Harrods - Domer model the association to national income growth levels is directed with savings ratio and capital formation.

Gulcan, Y., \& Bilman, M. E (2005), established the correlation between Turkey's real exchange rate and the budget deficit for 1960 and 2003. The end outcome revealed that the close correlation between the budget deficit and the real exchange rate was significant.

Kamal, U., \& M, K., et.al (2014), perceived the effect of the exchange rate (ER) on the growth rate of Bangladesh's economy from 1973 to 2013. The empirical study applied the ADF test, the test of causality for Granger, and the model of co-integration for Johansen. The result illustrates a significant long-term positive correlation between the exchange rate and economic development. The causality test shows that between ER and EG there is a bi-directional causality.

Kogid, M., et.al (2013), analyzed with-time series data the effect of exchange rates on the growth rate of Malaysia from 1971 to 2009. The consequence of the ARDL Bound test expresses long-term co-integration with a positive significant correlation between nominal than real exchange rates and economic growth. The ECM-based ARDL result, likewise shows that mutually real and nominal exchange rates have direct causal effects on economic growth.

Srinivasakumar, et.al (2015), studied with time-series data the relation between inflation, capital formation, and economic growth in India around 1950-51 and 2011-12. At first difference under the ADF test, all the data were stationary. Also, the study result showed a strong long-term correlation between capital formation, inflation, as well as economic growth.

Tufail, M. K., et.al (2014), observed the relation with time-series data for 1972-2011 between Pakistan's trade deficit and budget deficit. The Johansen Co-integration test presented that budget deficit, real GDP, and trade openness have a positive as well as a significant impact on the trade deficit, whereas the financial growth and the exchange rate have an adverse and significant effect on the trade deficit. The outcome further showed a short-run connection exists. The Granger causality test was shown the existence of bidirectional between the variables. 
Ugochukwu, S., et.al (2014), considered Nigeria's relationship with annual data during 1986-2012 midst capital formation and foreign direct investment. The analysis began with the ADF test which at the first difference showed the stationary of all the variables. The Co-integration test for Johansson suggests that exist long-term connotation among the variables. The Granger causality test result exhibited bidirectional and unidirectional causality between variables

\section{Hypothesis of the Study}

$\mathbf{H 0}=$ there is an insignificant linkage between dependent and independent variables.

$\mathbf{H 1}=$ there is a significant linkage between dependent and independent variables.

\section{Conceptual Framework}

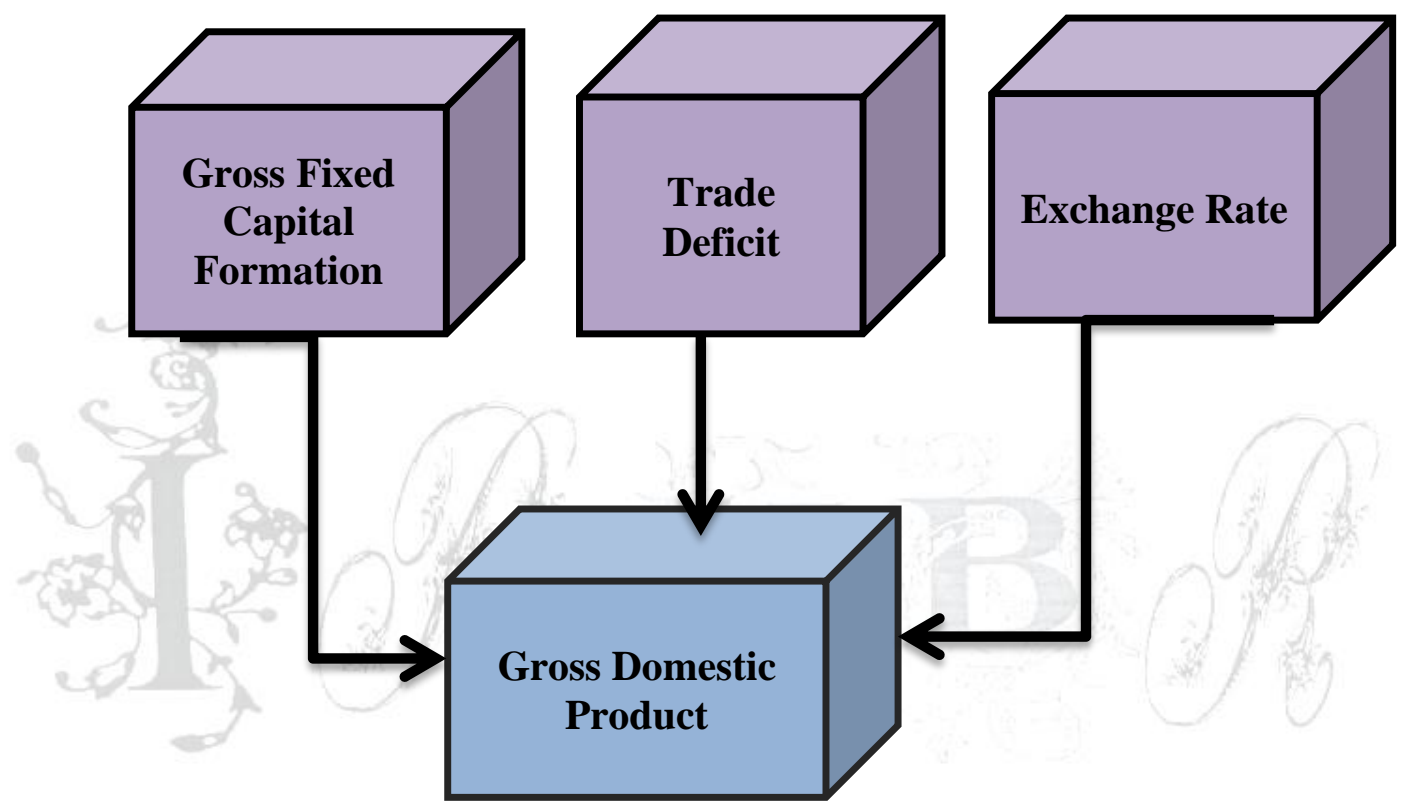

\section{Empirical Techniques}

$G D P=f(G F C F, T D, E X C H)$

$\mathrm{Y}=\beta_{0}+\beta_{1} X_{1}+\beta_{2} X_{2}+\beta_{3} X_{3}+\mu_{t}$

$G D P=\beta_{0}+\beta_{1}(G F C F)+\beta_{2}(T R D)+\beta_{3}(E X H R)+\mu_{t}$

Where

GDP = Gross Domestic Product

GFCF $=$ Gross Fixed Capital Formation .

$T D=$ Trade Deficit .

EXCH= Exchange Rate

$\mu t=$ Stochastic error.

\section{Methodology of the Study}

The various methodical methods are used for stationary and causality among variables, such as Augmented Dickey-Fuller (ADF) and Phillip Perron (PP) unit root test, long-term Johansen co-integration test, shortterm Error Correction Model, and Granger causalities. 


\section{Data Sources}

The study took the data from 1986 to 2013 years with time series, and attained from secondary sources; such as the World Development Indicator and Pakistan Bureau of Statistics websites.

\section{Research Design}

Research design is the structure and policy for finding the affiliation among the included variables. For this research, the experimental research is approved as a research design which provides a more valid and correct description of the variables that are related to the research questions.

\section{Data Analysis}

\section{Unit Root Test}

Table 1: ADF test at Level and First Difference

\begin{tabular}{|lllllll|}
\hline & \multicolumn{1}{c}{ Level } & \multicolumn{5}{c|}{ First Difference } \\
\hline & Intercept & $\begin{array}{l}\text { Trend and } \\
\text { Intercept }\end{array}$ & None & Intercept & $\begin{array}{l}\text { Trend and } \\
\text { Intercept }\end{array}$ & None \\
\hline GDP & 0.900820 & -1.632233 & 2.236047 & $-5.073822^{*}$ & $-5.598431^{*}$ & $-4.353962^{*}$ \\
& $(0.9939)$ & $(0.7528)$ & $(0.9921)$ & $(0.0004)$ & $(0.0006)$ & $(0.0001)$ \\
GFCF & 0.494664 & -1.904099 & 2.504585 & $-3.637953^{*}$ & $-3.693922^{*}$ & $-3.119068^{*}$ \\
& $(0.9833)$ & $(0.6236)$ & $(0.9958)$ & $(0.0119)$ & $(0.0410)$ & $(0.0031)$ \\
TD & $-4.521087 *$ & $-5.077922^{*}$ & $-3.912163^{*}$ & $-8.628704^{*}$ & $-8.447374^{*}$ & $-8.800875^{*}$ \\
& $(0.0014)$ & $(0.0018)$ & $(0.0004)$ & $(0.0000)$ & $(0.0000)$ & $(0.0000)$ \\
EXCH & 2.635706 & 2.745423 & 2.652170 & $-11.11480 *$ & $-11.84308^{*}$ & $-10.46538^{*}$ \\
& $(1.0000)$ & $(1.0000)$ & $(0.9968)$ & $(0.0000)$ & $(0.0000)$ & $(0.0000)$ \\
\hline
\end{tabular}

Source: E-views Version 9 (1986-2013)

The ADF test illustrates that the probability values of each variable (excluding trade deficit) are not integrated at a significance level of $5 \%$. But at this point, under the ADF test at the first difference, we checked stationary again and all variables are stationary at a 5\% significance level at the first difference

Table 2: Phillip Peron unit root test at Level and First Difference

\begin{tabular}{|c|c|c|c|c|c|c|}
\hline & \multicolumn{3}{|c|}{ Level } & \multicolumn{3}{|c|}{ First Difference } \\
\hline & Intercept & $\begin{array}{l}\text { Trend and } \\
\text { Intercept }\end{array}$ & None & Intercept & $\begin{array}{l}\text { Trend and } \\
\text { Intercept }\end{array}$ & None \\
\hline GDP & $\begin{array}{l}1.739377 \\
(0.9994)\end{array}$ & $\begin{array}{l}-1.531894 \\
(0.7928)\end{array}$ & $\begin{array}{l}3.485880 \\
(0.9996)\end{array}$ & $\begin{array}{l}-5.073845^{*} \\
(0.0004)\end{array}$ & $\begin{array}{l}-6.162242 * \\
(0.0002)\end{array}$ & $\begin{array}{l}-4.349257 * \\
(0.0001)\end{array}$ \\
\hline GFCF & $\begin{array}{l}0.300708 \\
(0.9739)\end{array}$ & $\begin{array}{l}-1.556848 \\
(0.7833)\end{array}$ & $\begin{array}{l}2.165677 \\
(0.9908)\end{array}$ & $\begin{array}{l}-3.655411 * \\
(0.0114)\end{array}$ & $\begin{array}{l}-3.713563 * \\
(0.0394)\end{array}$ & $\begin{array}{l}-3.119068^{*} \\
(0.0031)\end{array}$ \\
\hline TD & $\begin{array}{l}-4.516133 * \\
(0.0014)\end{array}$ & $\begin{array}{l}-5.077922 * \\
(0.0018)\end{array}$ & $\begin{array}{l}-3.938023 * \\
(0.0003)\end{array}$ & $\begin{array}{l}-24.18496 * \\
(0.0001)\end{array}$ & $\begin{array}{l}-23.50068 * \\
(0.0000)\end{array}$ & $\begin{array}{l}-21.22835^{*} \\
(0.0000)\end{array}$ \\
\hline EXCH & $\begin{array}{l}-3.797640 * \\
(0.0084)\end{array}$ & $\begin{array}{l}-6.333185^{*} \\
(0.0001)\end{array}$ & $\begin{array}{l}-1.473278 \\
(0.1285)\end{array}$ & $\begin{array}{l}-11.11480^{*} \\
(0.0000)\end{array}$ & $\begin{array}{l}-11.84308^{*} \\
(0.0000)\end{array}$ & $\begin{array}{l}-10.35924^{*} \\
(0.0000)\end{array}$ \\
\hline
\end{tabular}

Source: E-views Version 9 (1986-2013) 
The p-value of each variable (instead of exchange rate and trade deficit) is not integrated at a significance level of 5\%. Afterward, we verified at the first difference stationary again and found that the entire variable is stationary at first difference correspondingly in the Phillip Perron test

Johansen Co-integration

Table 3: Trace Test Result

\begin{tabular}{|lllll|}
\hline Hypothesized No & Eigenvalue & Trace Value & 5\% Critical level & Probability** \\
\hline None * & 0.908540 & 104.5187 & 47.85613 & 0.0000 \\
At most 1 * & 0.738548 & 47.11429 & 29.79707 & 0.0002 \\
At most 2 & 0.302343 & 14.91816 & 15.49471 & 0.0609 \\
At most 3 * & 0.230153 & 6.277515 & 3.841466 & 0.0122 \\
\hline
\end{tabular}

Source: E-views Version 9 (1986-2013)

The result of the Trace test showing the rejection of $\mathrm{H}_{0}$ at None $*$, most $1 *$, and most $3 *$ since its trace value is higher and the probability value is less than $5 \%$. This shows the long-term existence of correlation among variables.

Table 4: Maximum Eigenvalue Test Result

\begin{tabular}{|c|c|c|c|c|}
\hline None * & 0.908540 & 57.40438 & 27.58434 & 0.0000 \\
\hline At most $1 *$ & 0.738548 & 32.19613 & 21.13162 & 0.0009 \\
\hline At most 2 & 0.302343 & 8.640648 & 14.26460 & 0.3173 \\
\hline At most $3 *$ & 0.230153 & 6.277515 & 3.841466 & 0.0121 \\
\hline
\end{tabular}

Source: E-views Version 9 (1986-2013)

The result of Maximum Eigenvalue showing the rejection of $\mathrm{H}_{0}$ at None $*$, most of $1 *$, and most of $3 *$ since it Maximum Eigenvalue is higher and its probability value is less than 5\%. This demonstrates the presence of a long-term relationship between the variables.

Johansen long run co-integration equation from VCEM

$\mathrm{GDP}=-6611512-0.001905 \mathrm{GFCF}-304.1303 \mathrm{TRD}+8.053941 \mathrm{EXC}$

Error Correction Model

Table 5: Error Correction Model Result

\begin{tabular}{|lllll|}
\hline & Coefficient & $\begin{array}{l}\text { Standard } \\
\text { Error }\end{array}$ & t-Statistic & Probability \\
\hline ECM (-1) C (1) & -0.492731 & 0.156829 & -3.141838 & 0.0072 \\
GFCF C (2) & $1.04 \mathrm{E}-05$ & $9.51 \mathrm{E}-05$ & 0.109339 & 0.9141 \\
TRD C (3) & 2.538855 & 4.895848 & 0.518573 & 0.6100 \\
EXCH C (4) & -0.106858 & 0.113324 & -0.942948 & 0.3575 \\
Constant C (5) & 405751.5 & 158797.8 & 2.555146 & 0.0193 \\
\hline
\end{tabular}

Source: E-views Version 9 (1986-2013)

The table indicates that the coefficient of ECM (-1) is -0.492731 which has an approximate negative value, but still at 0.05 of significant levels as statistically significant. This also means that the long-term disequilibrium would be improved by $49.27 \%$ in the short run. The conclusion further expresses that the 
exchange rate is adverse, but insignificantly connected to GDP, whereas in the short run GFCF and TRD and GFCF hold a progressive as well as insignificant interconnection to GDP.

Table 6: Result of Granger causality

\begin{tabular}{|lllll|}
\hline $\begin{array}{l}\text { Direction of } \\
\text { causality }\end{array}$ & P-value & Lag & $\begin{array}{l}\text { Observ } \\
\text { ation }\end{array}$ & Outcome \\
\hline GFCF $>$ GDP & 0.6035 & 1 & 27 & GFCF does not cause GDP \\
GDP $>$ GFCF & 0.0405 & 1 & 27 & GDP causes GFCF \\
TRD>GDP & 0.9681 & 1 & 27 & TRD does not cause GDP \\
GDP> TRD & 0.0881 & 1 & 27 & GDP does not cause TRD \\
EXCH $>$ GDP & $5 . E-05$ & 1 & 25 & EXCH does not cause GDP \\
GDP $>$ EXCH & 0.0017 & 1 & 25 & GDP cause EXCH \\
TRD $>$ GFCF & 0.8918 & 1 & 27 & TRD does not cause GFCF \\
GFCF $>$ TRD & 0.0589 & 1 & 27 & GFCF does not cause TRD \\
EXCH $>$ GFCF & 0.5019 & 1 & 25 & EXCH does not cause GFCF \\
GFCF $>$ EXCH & 0.0002 & 1 & 25 & GFCF cause EXCH \\
EXCH $>$ TRD & 0.3430 & 1 & 25 & EXCH does not cause TRD \\
TRD $>$ EXCH & 0.3465 & 1 & 25 & TRD does no cause EXCH \\
\hline
\end{tabular}

Source: E-views Version 9 (1986-2013)

The Granger causality test shows that GFCF does not cause GDP, but GDP causes GFCF, which suggests a unidirectional causality between GFCF and GDP. TRD and GDP do not influence each other; therefore no correlation exists between TRD and GDP. EXCH does not affect GDP, but GDP causes EXCH, which implies a one-way causality between EXCH and GDP. EXCH does not cause GFCF again, but GFCF causes Exchange to demonstrate the unidirectional relationship between EXCH and GFCF. Otherwise, no causal relationship exists between TR and GFCF and EXCH and TRD.

\section{Conclusion}

The paper studies Pakistan's short-term and long-term relation and causality with time-series data between Gross Fixed Capital Creation, Exchange rate, Trade Deficit, and Gross Domestic Product from 1986-2013. After discovering, the variables of the entire variables are integrated at the first difference. The consequence of Johansen's Co-integration demonstrates the presence of long-term association of control variables with Gross Domestic Product. The ECM's result showed that in the short run, $49.27 \%$ of instability were improved in the long run. Besides, the Granger causality test demonstrated the existence of unidirectional causation among some variables.

\section{Policy Implication}

The policy implications of the current study are moderately steady. The potential of domestic and international resources and the amount of capital accumulation are generally more significant determinants of Pakistan's economic growth. The Government of Pakistan is expected to deliver export monetary and fiscal strategies aimed at growing its exports, generating more opportunities for capital accumulation as well as growth rates for Gross Domestic Products and reducing distortion of exchange rates, volatility, and general mismanagement.

\section{Recommendations}

Based on the findings, the existential analysis supports the following measures to achieve significant and sustained economic development. 
1. Governments should increase the production of products and services, and increased imports of intermediate goods are also important for the Economy.

2. The government should adjust the composition of its revenue. This must be firmly dependent on domestic production activities, which has to lead to an increase in the export of primary commodities.

3. To reduce imports and increase exports, the Government should work to develop domestic industries to address the global trade deficit.

4. To increase local productivity, more national and foreign industries within the country must be developed by the government. The situation would be beneficial in fulfilling internal needs. Yet exports from the economy would also rise with time.

5. Government spending on speculative enterprises should be decreased and investment in real economic sectors should be required to increase capital accumulation.

\section{Limitation of the Study}

There are several limitations of the proposed paper under discussion

1. The statistical data is composed only from the websites of the World Development Indicator and the Statistics Bureau of Pakistan.

2. The current study period is very short, and that should be increased.

3. In this analysis only basic methodology has used i-e unit root test, Johansen Co-integration test, Error Correction Model, as well as Granger causality.

\section{References}

Adhikary, B. K. (2011). FDI, trade openness, capital formation, and economic growth in Bangladesh: a linkage analysis. International Journal of Business and Management, 6(1), 16.

Ahmad, N., Ahmed, R. R., Khoso, I., Palwishah, R. I., \& Raza, U. (2014). Impact of Exchange Rate on Balance of Payment: An Investigation from Pakistan. Research Journal of Finance and Accounting, $5(13)$.

Ahmed. N., Ahmed. U., Hayat, F.M., \& Luqman. M. (2013) Relationship between Trade Deficit and Economic Growth in Pakistan: An Econometric Investigation, Australian Journal of Basic and Applied Science, 7 (7), 963-967.

Ainabor, A. E., Shuaib, I. M., \& Kadiri, A. K. (2014). Impact of capital formation on the growth of Nigerian Economy 1960-2010: Vector Error Correction Model (VECM). School of Business Studies, Readings in Management and Social Studies, 1(1), 132-154.

Bakare, A. S. (2011). The Impact of Capital Formation on the Growth of Nigerian Economy": Causality Approach. Far East Journal of Psychology and Business, 13(1), 2-13.

Bayar, Y. (2014). Effects of economic growth, export and foreign direct investment inflows on unemployment in Turkey. Investment Management and Financial Innovations, 11(2), 20-27.

Bhatt, V. V. (1959). Savings and capital formation. Economic Development and Cultural Change, 7(3, Part 1), 318-342.

Chen, J. (2012). Real exchange rate and economic growth: evidence from Chinese provincial data (19922008).

Gulcan, Y., \& Bilman, M. E. (2005). The effects of budget deficit reduction in exchange rate: evidence from Turkey. Dokuz Eylül University DP Series, 5(07).

http://www.pbs.gov.pk

https://data.worldbank.org/data-catalog/world-development-indicators

Kamal, U., \& M, K., et.al (2014). Causality between Exchange rate and Economic Growth in Bangladesh, European Scientific Journal,November, 10(31), 1857 - 7881.

Kanu, S.I and Ozurumba, B. A. (2014). Capital Formation and Economic Growth in Nigeria, Global Journal of Human-Social Science: Economics, 14(4), 249-460. 
Knyviene, I., Girdzijauskas, S., Grundey, D. (2010), "Market Capacity from the Viewpoint of Logistic Analysis", Technological and Economic Development of Economy, Vol. 16, No 4, pp.690-702.

Kogid, M., Asid, R., Lily, J., Mulok, D., \& Loganathan, N. (2012). The Effect of Exchange Rates on Economic Growth: Empirical Testing on Nominal Versus Real [dagger]. IUP Journal of Financial Economics, 10(1), 7.

Malik, U et al., (2015). The trade Balance of Pakistan and its Impact on Exchange Rate of Pakistan: A Research Report, Journal of Economics and Sustainable Development, 6(15), 222-1700.

Muhammad, N., Rasheed, A., \& Husain, F. (2002). Stock Prices and Exchange Rates: Are they related? Evidence from South Asian Countries [with Comments]. The Pakistan Development Review, 535-550.

Rajni, P., (2013). Linkage between Export, Import and Capital Formation in India. International Research Journal of Social Science, 2(3), 16-19.

Razi, A., Shafiq, A., Ali, S. A., \& Khan, H. (2012). Determinants of exchange rate and its impact on Pakistani economy. Global Journal of Management and Business Research, 12(16).

Srinivasakumar, V., Renganathan, R., \& Vijayabanu, C. (2015). Capital Formation and Inflation on Economic Growth in India: A Causality Analysis. Research Journal of Applied Sciences, Engineering and Technology, 9(12), 1148-1152.

Thirlwall, A. P. (2000). Trade, trade liberalization and economic growth: theory and evidence. African Development Bank.

Tufail, M. K., Anwar, S., Raza, S. H., \& Abbas, K. (2014). Effect of budget deficit on trade deficit in Pakistan (a time series analysis). Journal of Finance and Economics, 2(5), 145-148.

Ugochukwu, S., Judith, N., \& Edith, O. (2014). The impact of foreign direct investment on capital formation in Nigeria: A co-integration approach. The International Journal of Finance and Management, 2(2), 188-196.

Ugochukwu, U. S., \& Chinyere, U. P. (2013). The impact of capital formation on the growth of Nigerian economy. Research Journal of Finance and Accounting, 4(9), and 36-4.

www.finance.gov.pk/finance_economic_survey.aspx 